\title{
Desmocysta hadra, a new Late Cretaceous dinoflagellate cyst species: stratigraphic range, palaeogeographic distribution and palaeoecology
}

\author{
Manuel Vieira $^{1}$ and Salih Mahdi $^{2}$ \\ ${ }^{1}$ Shell UK Ltd., 1 Altens Farm Road, Nigg, Aberdeen, AB12 3FY, UK \\ ${ }^{2}$ RPS Energy Ltd., Century House, Gadbrook Business Centre, Northwich, Cheshire, CW9 7TL, UK \\ Correspondence: Manuel Vieira (manuel.vieira@shell.com)
}

Received: 20 May 2020 - Revised: 31 July 2020 - Accepted: 14 August 2020 - Published: 8 October 2020

\begin{abstract}
A new species of dinoflagellate cyst, Desmocysta hadra sp. nov., is described from the early Campanian (Late Cretaceous) in the Norwegian Sea. This new taxon differs from the other three known species by its particularly robust but highly folded wall and the short, fine filaments arising from the antapex. The short stratigraphic range of early Campanian for this new species was calibrated with other regional well-dated dinoflagellate cysts, making it a good biostratigraphic marker. A review of the taxonomic description of the genus has also been undertaken using the available published data. The available data shows a consistent presence of Desmocysta in the fossil record from the Early Cretaceous to the late Paleocene, although some Late Jurassic occurrences have been reported in the North Sea Basin. The current records also indicate that this genus is restricted to higher latitudes in the Northern Hemisphere. Based on Paleocene and Late Cretaceous occurrences of the genus, and its association with dinoflagellate cysts, prasinophytes and acritarchs, a proximal, highly stressed marine environment for Desmocysta is suggested.
\end{abstract}

\section{Introduction}

The genus Desmocysta was defined by Duxbury (1983, p. 43) in his palynological study of Aptian to lower Albian sediments from the Lower Greensand Group on the Isle of Wight (southern England). The genus name is derived from the Greek desmos, a cable, and kystis, a cell or sac, in reference to the characteristic antapical filaments linked to relatively featureless cysts. This genus comprises spheroidal to ovoidal cysts exhibiting virtually absent tabulation except where indicated by a two-plate precingular archaeopyle, although the precise plate equivalence cannot be determined. As described by Duxbury (1983), every cyst possesses fine and long filaments extending from the antapex.

The diagnosis of the first published species, Desmocysta plekta, is similar to that of the genus, although it is mentioned that the long fine filaments ( 10 or more individual filaments) extend from a small area at the antapex and exhibit a length twice as long as the length of the main body or cap- sule (Duxbury, 1983, text figs. 20-21). The filaments often terminate in a granular amorphous mass.

In the genus remarks, Duxbury referred to the apparent resemblance to Ophiobolus lapidiaris Wetzel (1933), which possesses an ovoidal main structure with a smooth to microgranulate surface with some strands or filaments connected to the main body. Often, observation of these filaments may be difficult. Evitt (1968) suggested that Ophiobolus could represent the egg case of a planktonic organism and the strands or filaments represent either attachments or buoyancy aids to support the eggs in the planktonic stage. Duxbury (1983) discussed Evitt's (1968) theory and mentioned that some features in the central body figured in Evitt's paper could be considered sutural splits between precingular plates. Although Duxbury (1983) only defined a single species of Desmocysta, he mentioned that other species should exist, referring specifically to Ophiobolus sp. A of Davey (1979) and the unpublished Klementia barbata of Warren (1967). Klementia barbata was subsequently formalised as Warrenia californica Monteil (1992), a single species of the genus Warrenia 
comprising smooth to verrucate or spinose ovoidal cysts with no clear tabulation except for a two-plate precingular archaeopyle with or without antapical filaments. The type material from southern France supports a stratigraphic range from the late Tithonian to early Valanginian. Duxbury (1983) also stated that the genus Desmocysta differs from the genus Scuticabolus Loeblich (1967) in that the latter genus has some type of apical (or at least pre-precingular) archaeopyle as opposed to the 2P type diagnosed in Desmocysta.

Duxbury (2001) described Desmocysta simplex from late Hauterivian sediments from the central North Sea (UK) as the first formal description of Ophiobolus sp. A Davey (1979). Desmocysta simplex exhibits similarities to Desmocysta plekta, although the cyst is generally larger and possesses fewer antapical filaments.

Duxbury (2018) included smooth to granulate and/or verrucate forms with or without antapical filaments in the genus Desmocysta, and Warrenia californica Monteil (1992) was emended and transferred to Desmocysta californica. This species exhibits a thin wall comparable with Desmocysta plekta, and there is clear evidence for the presence of surface granules and/or verrucae on the cyst (see Plate 2, figs. 5 and 6).

Since the definition of this genus, occurrences of Desmocysta plekta have been reported in several publications ranging from the Barremian of northwest Greenland and the North Atlantic (Nøhr-Hansen, 1993; Ogg, 1994) to the Thanetian of southeast England (Jolley, 1992, 1998) (Fig. 1). The other two species (D. simplex and D. californica) have not yet been reported further in published literature after their formal definition. Representatives of this genus have also been observed in Late Jurassic, middle-early Kimmeridgian, late Kimmeridgian and middle Volgian material, including common occurrences in the late Kimmeridgian of UKCS Block 14/19 (Stan Duxbury, personal observation, 2020).

In this paper, we describe a new species of Desmocysta and discuss the stratigraphic relevance of this genus, its geographic distribution and previously unpublished records from the Shell northwest Europe offshore microfossil database.

\section{Material and methods}

The Desmocysta specimens identified and illustrated here are from cutting samples collected from the 6304/3-1 well drilled in the Norwegian Sea.

The available cuttings were treated to standard palynological preparation techniques, including acid digestion using hydrochloric acid $(\mathrm{HCl})$ to eliminate carbonates and hydrofluoric acid (HF) to eliminate silicates. The resulting residue was subject to oxidation using concentrated nitric acid $\left(\mathrm{HNO}_{3}\right)$. The remaining organic fraction was sieved through a $20 \mu \mathrm{m}$ mesh nylon sieve to concentrate the kerogen, which was then air-dried on coverslips and mounted on slides using Petropoxy 154 resin as permanent mounts. Slides were scanned under a Leica DM 1000 microscope, and the specimens were identified, counted and described. All photographs were taken using a Leica MC170HD camera.

The illustrated specimens are identified by their sample depth, followed by the respective position using England Finder (EF) co-ordinates. The slide with the new species holotype is deposited at the Natural History Museum in the London palynology slide repository. The suprageneric classification follows Fensome et al. (1993). The morphological terminology follows Stover and Evitt (1978) and Williams et al. (2000).

\section{Systematic palaeontology}

Division Dinoflagellata (Bütschli 1885) Fensome et al. 1993

Subdivision Dinokaryota Fensome et al. 1993

Class Dinophyceae Pascher 1914

Subclass Peridiniphycidae Fensome et al. 1993

Order Gonyaulacales Taylor 1980

Family uncertain

Genus Desmocysta Duxbury 1983

\section{Remarks}

Duxbury (1983) used the presence of long, fine filaments extending from the antapex (sometimes twice as long the length of the cyst) as a feature to define the genus Desmocysta. The present work includes in this genus species with short filaments and particularly robust and highly folded cysts.

\section{Type species}

Desmocysta plekta Duxbury, 1983

Desmocysta hadra sp. nov.

Plate 1, figs. 1-12

\section{Derivation of name}

From the Greek hadros, well-developed, bulky and stout, referring to the robust nature of this species.

\section{Diagnosis}

A subspherical to ovoidal dinoflagellate cyst with a two-plate precingular archaeopyle. The wall is thick, up to $2 \mu \mathrm{m}$, and highly folded with a scabrate-punctate surface. Fine, usually short filaments arise from a small area at the antapex (Fig. 2). 


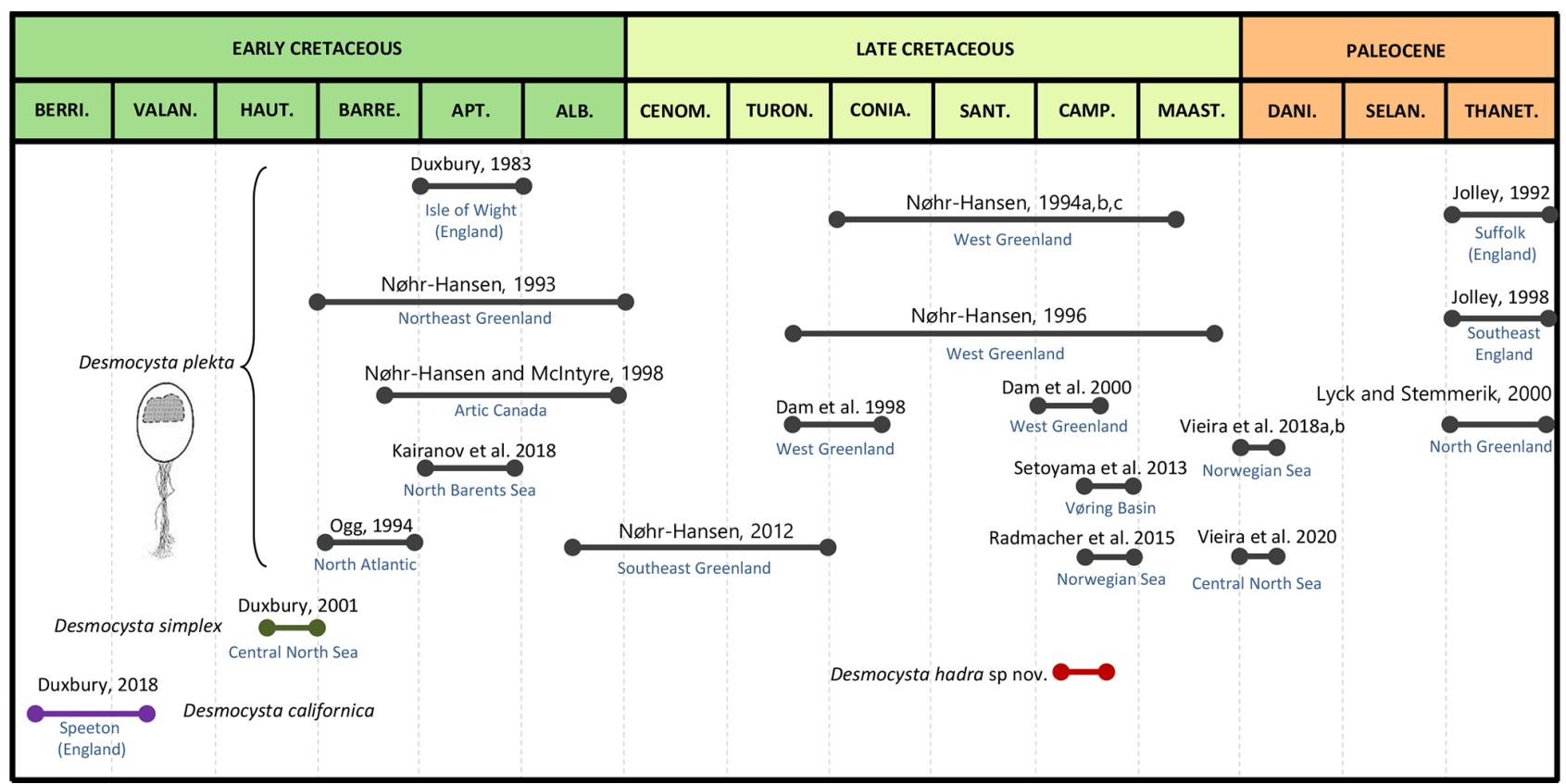

Figure 1. Summary of the published chronostratigraphic occurrences of Desmocysta species by author and geographic distribution.

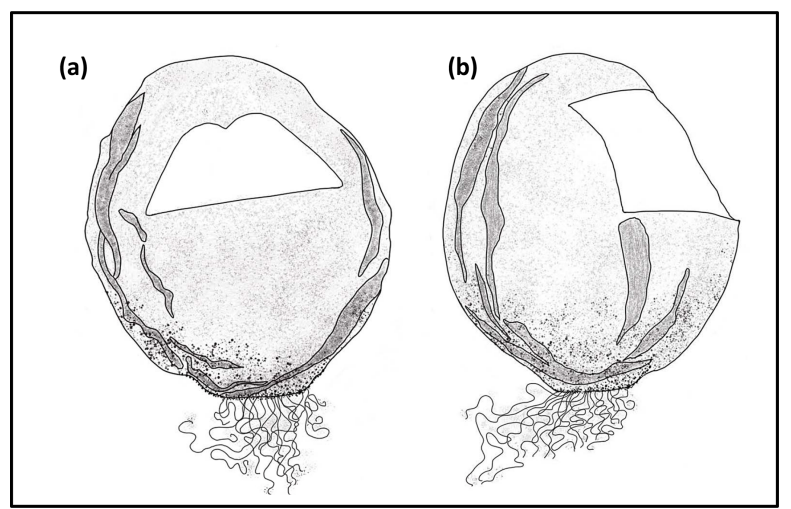

Figure 2. Interpretative drawing of Desmocysta hadra sp. nov. (a) Dorsal view; (b) left-lateral view.

\section{Holotype}

Plate 1, fig. 1; from a cutting sample at $3495 \mathrm{~m}$; EF coordinates $\mathrm{J} 57 / 3$; central body length $58 \mu \mathrm{m}$, width $48 \mu \mathrm{m}$, length of filaments $15 \mu \mathrm{m}$.

\section{Stratigraphic horizon}

Early Campanian of well 6304/3-1.

\section{Description}

The dinoflagellate cyst is of intermediate size, subspherical to ovoidal in shape and highly folded. These folds usually seem to run approximately parallel to the margin of the cyst.
The wall is thick, up to $2 \mu \mathrm{m}$, and scabrate-punctate. The fine grana are well-developed, up to $3 \mu \mathrm{m}$, tending to concentrate in the lower third of the body where the filaments originate. The filaments are usually short, fine and threadlike (occasionally some specimens show longer filaments), arising from the antapex and usually less than $1 / 3$ the length of the cyst. The archaeopyle is two-plate precingular, and the operculum is usually free, although the opercular pieces can occasionally be seen inside the cyst (see Plate 1 - figs. 4 and 7). In some cysts it is possible to observe a small incision between the two archaeopyle plates. The presence of opercular pieces inside the cyst, together with a highly folded wall and well-developed granulation particularly concentrated in a small area where the filaments are attached to the antapex, is not reported in other Desmocysta species.

\section{Dimensions}

Central body length $46(58) 67 \mu \mathrm{m}$, width $43(49) 61 \mu \mathrm{m}$, length of filaments $10(24) 35 \mu \mathrm{m}$. Number of specimens measured 20.

\section{Remarks}

This new species differs from D. plekta (Plate 2, figs. 1-4) by its larger size, thicker wall and shorter filaments, as well as from $D$. simplex (Plate 2, fig. 7) by its numerous, relatively short antapical filaments. Desmocysta californica (Plate 2, figs. 5-6) differs by the presence of granules and/or verrucae on its surface. Desmocysta hadra sp. nov. also differs from those species by its highly folded wall and the concentration 

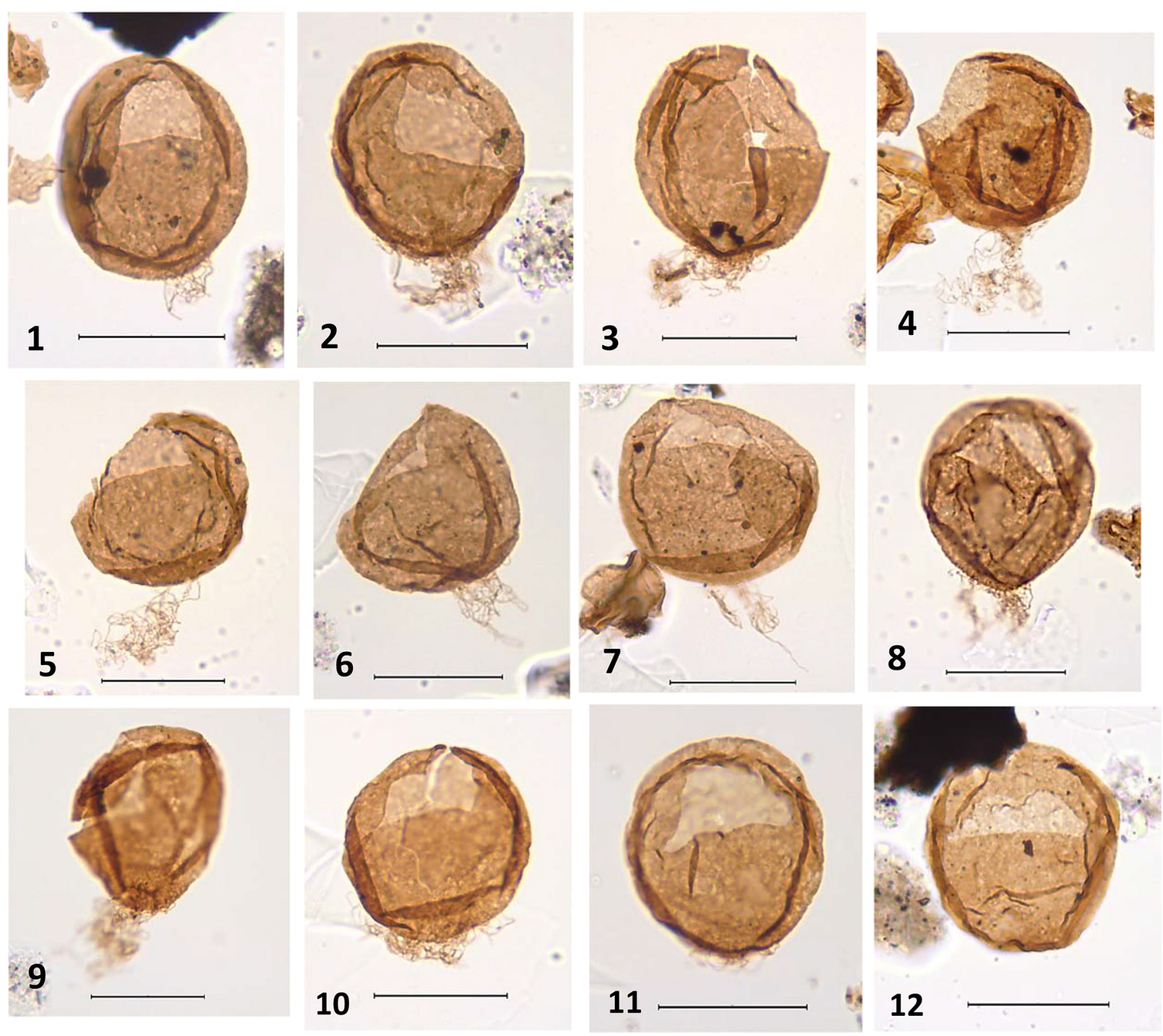

12

Plate 1. The scale bar represents $40 \mu \mathrm{m}$ for all specimens. (1-12) Desmocysta hadra sp. nov. All specimens were recovered from cutting samples at $3495 \mathrm{~m}$ in the 6304/3-1 well. (1) Holotype. Specimen in dorsal orientation exhibiting the finely granular ornament, mainly concentrated towards the antapex where the short filaments arise. Central body length $58 \mu \mathrm{m}$, width $48 \mu \mathrm{m}$, filaments length $15 \mu \mathrm{m}$; slide coordinate EF. J57/3. (2-12) Paratypes. (2) Specimen in dorsal orientation. Central body length $58 \mu$ m, width $48 \mu \mathrm{m}$, filaments length $24 \mu \mathrm{m}$; slide co-ordinate EF. N54/3. (3) Specimen in left-lateral orientation. Central body length $61 \mu \mathrm{m}$, width $57 \mu \mathrm{m}$, filaments length $20 \mu \mathrm{m}$; slide co-ordinate EF. U44/4. (4) Specimen in right-lateral orientation with the opercular plates inside the cyst. Central body length $56 \mu$ m, width $55 \mu \mathrm{m}$, filaments length $33 \mu \mathrm{m}$; slide co-ordinate EF. J56. (5) Specimen in right-lateral orientation. Central body length $54 \mu \mathrm{m}$, width $56 \mu \mathrm{m}$, filaments length $32 \mu \mathrm{m}$; slide co-ordinate EF. R51/2. (6) Specimen in right-lateral orientation. Central body length $56 \mu \mathrm{m}$, width $57 \mu \mathrm{m}$, filaments length $26 \mu \mathrm{m}$; slide co-ordinate EF. N44/4. (7) Specimen in dorsal orientation with the opercular plates detached but in situ inside the cyst. Central body length $62 \mu \mathrm{m}$, width $61 \mu \mathrm{m}$, filaments length $27 \mu \mathrm{m}$; slide co-ordinate EF. U43/4. (8) Specimen in dorsal orientation with the opercular plates detached but in situ, showing the finely granular ornament concentrated at the antapex. Central body length $62 \mu \mathrm{m}$, width $57 \mu \mathrm{m}$, filaments length $23 \mu \mathrm{m}$; slide co-ordinate EF. P46/2. (9) Specimen in right-lateral orientation with the opercular plates detached but in situ, clearly showing the finely granular ornament, which is mainly concentrated towards the antapex. Central body length $61 \mu \mathrm{m}$, width $52 \mu \mathrm{m}$, filaments length $28 \mu \mathrm{m}$; slide co-ordinate EF. U42. (10) Specimen in dorsal orientation. Central body length $56 \mu \mathrm{m}$, width $56 \mu \mathrm{m}$, filaments length $14 \mu \mathrm{m}$; slide co-ordinate EF. L50/2. (11) Specimen in dorsal orientation. Central body length $56 \mu \mathrm{m}$, width $53 \mu \mathrm{m}$, filaments length $10 \mu \mathrm{m}$; slide co-ordinate EF. F42/2. (12) Specimen in dorsal orientation showing the two-plate precingular archaeopyle. Central body length $57 \mu \mathrm{m}$, width $53 \mu \mathrm{m}$, filaments length $1 \mu \mathrm{m}$; slide co-ordinate EF. J59. 
of fine grana in the lower part of the body, particularly where the filaments originate.

\section{Associated taxa}

The sample from which the holotype is recorded is dominated by the new species (nearly $40 \%$ of the overall dinoflagellate cyst assemblage), together with the common Heterosphaeridium bellii-heteracanthum, Palaeoperidinium pyrophorum and Spiniferites ramosus group and frequent occurrences of Cerodinium diebelii, Chatangiella spp. and Trithyrodinium evittii. Other taxa recorded include rare $\mathrm{Al}$ terbidinium acutulum, Amphidiadema denticulata, Hystrichodinium pulchrum, Odontochitina diducta, Palaeohystrichophora infusorioides, Raphidodinium fucatum, Spongodinium delitiense and Trichodinium castanea. Frequent occurrences of the pollen type Aquilapollenites spp. are also recorded.

\section{Discussion}

\subsection{Taxonomic remarks}

The presence of a two-plate precingular archaeopyle is one of the defining features of the genus Desmocysta. Although there are some references to cysts attributed to Desmocysta exhibiting atypical morphologic features (NøhrHansen, 1993; Torricelli, 2000), those forms require further research in order to establish specific differences with the generic definition of Duxbury (1983). Nøhr-Hansen (1993) studied several sections of late-early Barremian to late Albian ages from east Greenland and reported the presence of Desmocysta plekta exhibiting the characteristic features of the species. In the same publication, Nøhr-Hansen recognised another form, very similar in size and appearance to D. plekta from a section of Albian age, although this cyst appears to have an apical archaeopyle (see Plate 2, fig. 8). That form was still included in the latter species, but according to Nøhr-Hansen (1993) the recognition of a different archaeopyle in this cyst type may support the definition of a new species and possibly a new genus.

Torricelli (2000) reported two dinoflagellate cysts identified as cf. Desmocysta plekta from late Albian samples of the Cismon core (southern Alps, northeast Italy). These specimens were referred to cf. D. plekta based on their similarity in size and appearance, although they show an apical archaeopyle. Analysing the published illustration (see Plate II, fig. 9), the cyst is subspherical in shape with a rounded apex and also does not seem to exhibit the defined antapical filaments characteristic of D. plekta, rather having what appear to be flange-like extensions. Duxbury (1983) suggested that the genus Scuticabolus may have an apical or precingular archaeopyle; possibly these forms reported by NøhrHansen (1993) and Torricelli (2000) could be included in the genus Scuticabolus. A restudy of the material of Nøhr-
Hansen (1993) and Torricelli (2000) might allow for a direct comparison of both forms with Desmocysta, allowing for some revision of the generic definition or description of a new genus.

\subsection{Biostratigraphy and palaeogeographic distribution}

Desmocysta hadra was identified in the upper part of the early Campanian aged sediments from well 6304/3-1 (offshore Norway). This species was consistently recorded in $30 \mathrm{~m}$ of mudstones across nine cutting samples in notable numbers $(10 \%-20 \%$ of the assemblage). In one of the analysed samples (at $3495 \mathrm{~m}$ ), Desmocysta hadra constitutes $42 \%$ of the overall dinoflagellate cyst assemblage. The FDO (first downhole occurrence) of the new species occurs below the FDO of Trichodinium castanea and Callaiosphaeridium asymmetricum in an assemblage dominated by Heterosphaeridium bellii-heteracanthum. The presence of $C$. asymmetricum and $T$. castanea suggests an age no younger than early Campanian (Costa and Davey, 1992; Fensome et al., 2009; Gradstein et al., 2010). The record of common to abundant $H$. bellii was also reported by Radmacher et al. (2014a, b, 2015) in middle-early Campanian aged sediments from Norwegian Sea and Barents Sea wells.

The LDO (last downhole occurrence) of Desmocysta hadra is observed below the FDO of Chatangiella manumii and the downhole increase in relative numbers of Trithyrodinium suspectum, Chatangiella niiga and Palaeohystrichophora infusorioides, events also observed within the early Campanian across the Norwegian Sea region. In the 6304/3-1 well, the LDO of Spongodinium delitiense occurs just $3 \mathrm{~m}$ above the LDO of Desmocysta hadra. According to several publications (Williams et al., 2004; Radmacher et al., 2014a, b) the oldest occurrence of $S$. delitiense is recorded in the early Campanian.

The short stratigraphic range of Desmocysta hadra observed in this well allows for the potential use of this species in regional biostratigraphy as an early Campanian marker. More wells need to be studied in order to confirm the stratigraphic range and the geographic distribution of this species.

In the Norwegian Sea, particularly in the Møre and Vøring basins, deep-sea turbidite systems deposited sandstone reservoirs throughout the Late Cretaceous interval. The use of short-range biostratigraphic markers with regional expression can be crucial for well correlations.

Desmocysta simplex, described in late Hauterivian sediments from the central North Sea, is also a good stratigraphic marker. The occurrence of this species has been recorded in many wells from the North Sea to the Barents Sea (Fig. 3). Desmocysta californica also exhibits a short stratigraphic range (Berriasian-early Valanginian), although the biostratigraphic calibration potential is more difficult to discuss due to the lack of published data. There are several reported occurrences of Desmocysta spp. in the Shell northwest Europe 

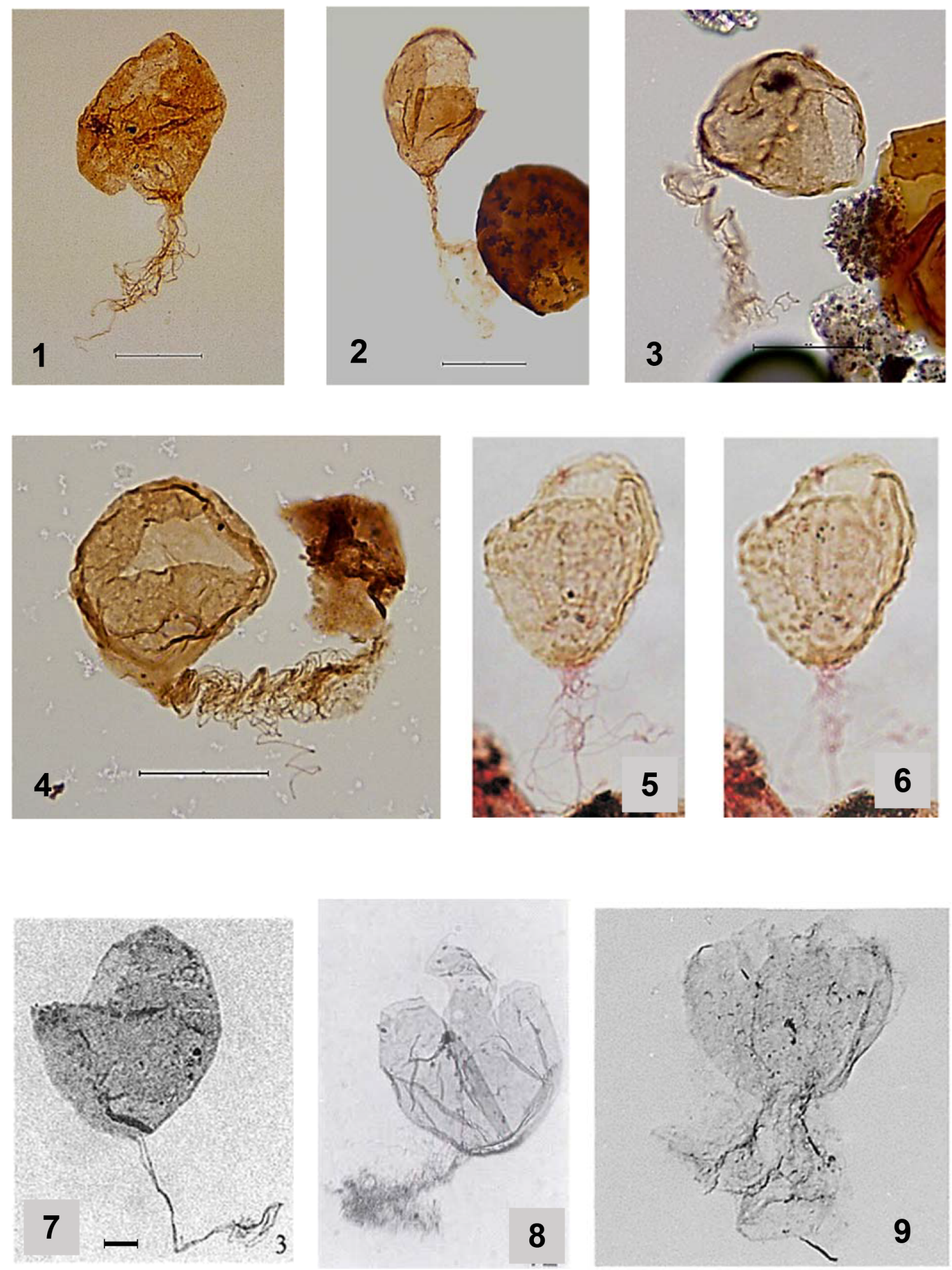

Plate 2. (1-4) Desmocysta plekta photographs from the Danian in the Ormen Lange field (Norwegian Sea basin). The scale bar represents $30 \mu \mathrm{m}$ for all specimens of D. plekta. (5-6) Desmocysta californica (Duxbury, 2018 plate 13, figs. 9 and 10). Specimens are from the Speeton Clay, early Valanginian. Duxbury illustrated the variations in the size of the granules and verrucae on the cyst surface and the long antapical filaments. (7) Desmocysta simplex (Duxbury, 2001 fig. 7.3). Paratype specimen in lateral orientation. Scale bar represents $10 \mu \mathrm{m}$. (8) Cyst attributed to Desmocysta plekta in Nøhr-Hansen (1993) Plate 7, fig. 12 exhibiting an apical archaeopyle. (9) Cyst attributed to cf. Desmocysta plekta in Torricelli (2000) Plate III, fig. 5 exhibiting an apical archaeopyle. 
microfossil database (Fig. 3), but without a definition to the species level we cannot be sure if they refer to Desmocysta californica, Desmocysta hadra or possibly other unpublished species.

Desmocysta plekta is the species with the most published occurrences. The fossil record extends from Barremian (Nøhr-Hansen, 1993) and North Atlantic (Ogg, 1994) to Thanetian (Jolley, 1992, 1998). Vieira and Jolley (2020) discussed the distribution of terrestrially sourced and marine palynomorphs in the Forties Sandstone Member, a deep marine turbidite fan system deposited from the late Thanetian (ca. 56.8 Ma) through the Ypresian (ca. 55.3 Ma). Rare occurrences of $D$. plekta have been recorded across a small number of wells, although they were considered to be reworked from older Thanetian sediments. If these occurrences were in situ, then the record of D. plekta will extend into the Ypresian.

Setoyama et al. (2013), in a study of a submarine fan system in the Vøring Basin (offshore Norway), used the first downhole occurrence (FDO) of D. plekta as a late Campanian marker, although due to its long stratigraphic range, it is difficult to use this species for age determination. Desmocysta plekta seems to be frequently recorded across the Campanian. Radmacher et al. (2015) recorded abundant specimens at that level in well 6707/10-1 in the Norwegian Sea.

Across the study area, Desmocysta hadra and D. plekta are noted to co-occur within the same stratigraphic interval. There is a possibility that previous palynological studies may have informally assigned $D$. hadra to Desmocysta spp., purely because it did not correspond to features already described for D. plekta or D. simplex.

All the known occurrences of Desmocysta californica, D. plekta and D. simplex discussed here are from the Northern Hemisphere. The Early Cretaceous occurrences extend across Arctic Canada (Nøhr-Hansen and McIntyre, 1998), northeast Greenland (Nøhr-Hansen, 1993), the north Barents Sea (Kairanov et al., 2018), the North Sea (Duxbury, 1983, 2001, 2018) and the North Atlantic (Ogg, 1994). There are also some unpublished records of D. simplex and D. plekta in Early Cretaceous sediments from the Jeanne d'Arc Basin, offshore Canada, and the north Caspian Sea, offshore Kazakhstan, that have been recorded in oil and gas wells (source: Shell Microfossil Database).

Other than D. hadra n. sp., only D. plekta occurs in the Late Cretaceous, extending from west Greenland (NøhrHansen, 1994a, b, c, 1996; Dam et al., 1998, 2000), southeast Greenland (Nøhr-Hansen, 2012) and offshore Norway (Setoyama et al., 2013; Radmacher et al., 2015). Paleocene records are limited to the Norwegian Sea (Vieira et al., 2018a, b), central North Sea (Vieira et al., 2020), northern Greenland (Lyck and Stemmerik, 2000) and southeast England (Jolley, 1992, 1998) (Fig. 1). The records from well data in the Shell northwest Europe offshore microfossil database, illustrated in Fig. 3, comprise mainly Cretaceous to Paleocene occur- rences from the southern North Sea Basin across to the Barents Sea Basin.

The palaeolatitude of the Cretaceous records shows that Desmocysta is mainly restricted to the boreal warm climate belt of Scotese et al. (2014). Only the Barremian record from the North Atlantic (Ogg, 1994) suggests the presence of this taxon in the latitude of the arid climatic belt (Fig. 4).

\subsection{Palaeoenvironmental remarks for the genus Desmocysta}

Although most of the published records of Desmocysta species refer to taxonomy or biostratigraphy, the Paleocene record seems to reveal more about the palaeoenvironmental preferences for Desmocysta plekta. In his study of the late Paleocene Thanet Beds in eastern England, Jolley (1992) reported in some sections the occurrence of Desmocysta plekta in association with Areoligera gippingensis in two of the defined association sequences (T6 and T8). Jolley discussed the fact that the taxa that accompany A. gippingensis in that interval appear to be related to biofacies associations. Three of the sections yielded associations of Leiosphaeridia spp., Desmocysta plekta and Paralecaniella indentata together with A. gippingensis. Jolley (1992) concluded that these taxa are apparently abundant in proximal, high-stress marine environments. Jolley (1998) published a similar association in a sample from the Pegwell Bay section, with the presence of D. plekta in an assemblage of abundant Areoligera cf. coronata, A. gippingensis and $P$. indentata. He also suggested that A. gippingensis is most common in turbid-water transgressive environments, which seems to indicate that in the late Paleocene D. plekta would prefer the same environmental conditions.

The Paleocene record of $D$. plekta in the Thyra $\varnothing$ Formation, Wandel Sea Basin (northern Greenland), from Lyck and Stemmerik (2000) shows dinoflagellate cyst assemblages composed mainly of peridinioids associated with $P$. indentata and abundant pollen, fungal spores and phytoclasts. The authors interpreted the deposition in a shallow, protected environment, and deposition most likely took place in shallowmarine lagoons and marshes due to the association of siltstones and coals. It was also noted that lack of bioturbation or the absence of marine macrofossils may indicate a biologically stressed (possible anoxic, suboxic) environment during deposition. This seems to suggest comparable environmental conditions as described by Jolley $(1992,1998)$, although Lyck and Stemmerik reported high amounts of Late Cretaceous reworking, making it questionable if the occurrence of D. plekta is actually in situ.

Vieira et al. (2018b) reported the occurrence of D. plekta from the Danian Egga reservoir in the Ormen Lange area (Norwegian Sea). The abundance generally increases downwards towards the lower part of the reservoir interval. In the samples with higher relative abundances, D. plekta is associated with abundant Areoligera coronata and a diverse as- 


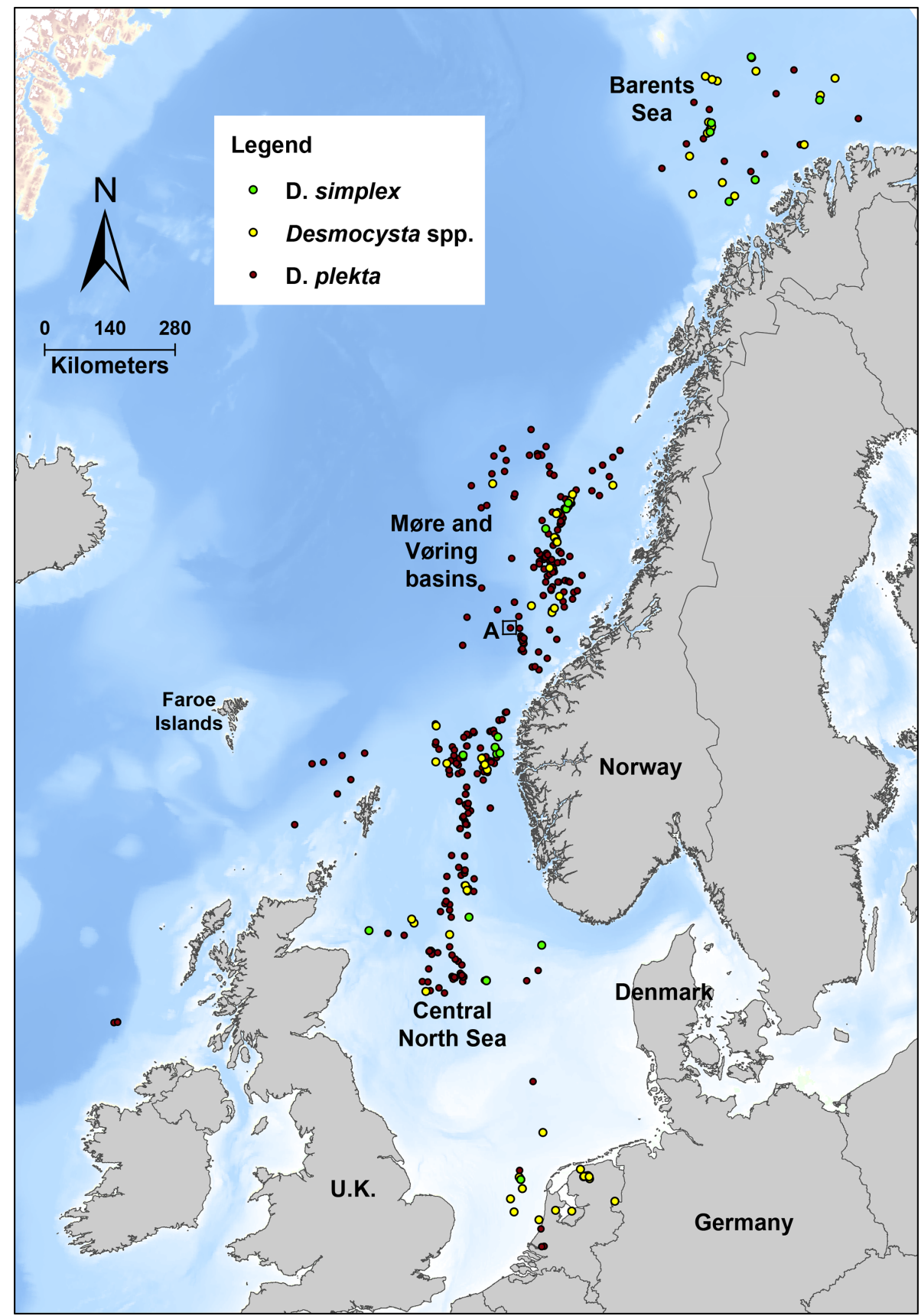

Figure 3. Geographical distribution of Desmocysta spp., D. simplex and D. plekta records from the Shell Microfossil Database. A: location of the Desmocysta hadra holotype well 6304/3-1. Source: Shell Microfossil Database.

semblage of peridinioid genera, including Palaeoperidinium, Palaeocystodinium, Deflandrea, Senegalinium and Trithyrodinium, as well as less abundant gonyaulacoids, such as $O p$ erculodinium, Spiniferites and Hystrichosphaeridium. Also noticeable is the consistent presence of Paralecaniella indentata in the assemblages, similar to those observed in the Thanetian sites described by Jolley (1992, 1998), which could infer that $D$. plekta could be part of an inner neritic plankton community tolerating turbid waters and stressed marine environments.

We do not have sufficient data from Cretaceous material to make consistent palaeoenvironmental assumptions, although Desmocysta hadra was recognised in assemblages dominated by Heterosphaeridium bellii-heteracanthum, which like most areoligeracean phototroph gonyaulacoids, is usually well-represented in more proximal facies. 

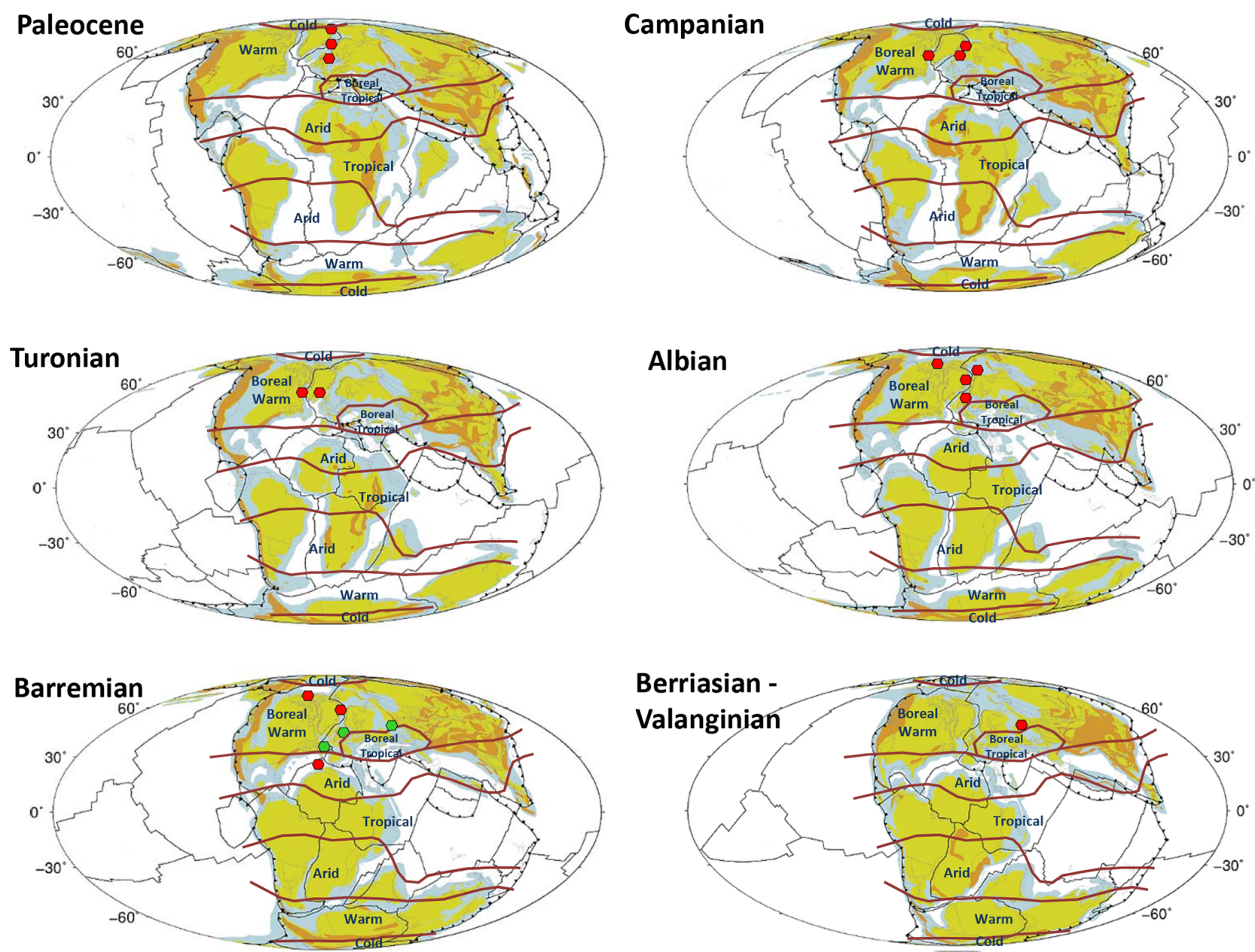

Figure 4. Distribution maps of Desmocysta plekta (red circles) and D. simplex (green circles) from the Early Cretaceous to the Paleocene. The base palaeogeographic maps are adapted from Cao et al. (2017), and the palaeoclimate zones are from Scotese et al. (2014).

Most of the data gathered from offshore wells, used to understand the potential palaeoenvironmental preference of the genus, targeted specific stratigraphic intervals with the occurrence of turbiditic facies; therefore, the discussed environmental preferences of this species can be biased due to focused sampling. We cannot exclude the occurrence of the genus in deeper marine settings as other wells in basinal areas need to be studied for comparison. Also, other environmental factors such as temperature, salinity and water stratification might affect the occurrence and abundance of Desmocysta spp. In addition, long-ranging species such as D. plekta might have variable preferences at different stratigraphic levels. More data will need to be gathered in order to clarify the potential palaeoenvironmental use of this genus.

\section{Conclusions}

This contribution formally describes Desmocysta hadra, identified in early Campanian sediments from the Norwegian Sea. This species seems to have a short stratigraphic range, making it a good biostratigraphic marker, while D. plekta has a much wider range, spanning from the Early Cretaceous to late Paleocene. The available published data show that the different species belonging to this genus are restricted to the higher latitudes in the Northern Hemisphere.

The defining features that characterise the unusual genus Desmocysta are also discussed to include a species with short, fine filaments as well as thick, robust and highly folded cysts exhibiting a unique scabrate-granular ornament typically increasing towards the antapex. The further study of cysts resembling Desmocysta but differing by possessing an apical archaeopyle remains in need of taxonomic treatment.

Although it is challenging to identify environmental preferences for fossil taxa, the genus Desmocysta is suggested here to have preferred turbid waters and stressed marine environments based on the available Paleocene and Late Cretaceous records. Future research might allow for a further discussion of other palaeoenvironmental controls on the occurrence of Desmocysta species. 


\section{Appendix A}

This Appendix alphabetically lists all formally described microfossil taxa below the generic level which are mentioned in this contribution, with full author citations following Fensome et al. (2019).

Alterbidinium acutulum (Wilson, 1967) Lentin and Williams, 1985

Amphidiadema denticulata Cookson and Eisenack, 1960

Areoligera coronata (Wetzel, 1933) Lejeune-Carpentier, 1938

Areoligera gippingensis Jolley, 1992

Cerodinium diebelii (Alberti, 1959) Lentin and Williams, 1987

Chatangiella manumii (Vozzhennikova, 1967) Lentin and Williams, 1976

Chatangiella niiga (Vozzhennikova, 1967) Lentin and Vozzhennikova, 1990

Desmocysta plekta Duxbury, 1983

Desmocysta simplex Duxbury, 2001

Desmocysta californica (Monteil, 1992) Duxbury, 2018

Heterosphaeridium bellii Radmacher et al., 2014a

Heterosphaeridium heteracanthum (Deflandre and Cookson, 1955) Radmacher et al., 2014a

Hystrichodinium pulchrum Deflandre, 1935

Odontochitina diducta Pearce, 2010

Palaeohystrichophora infusorioides Deflandre, 1935

Palaeoperidinium pyrophorum (Ehrenberg, 1837) Sarjeant, 1967

Paralecaniella indentata (Deflandre and Cookson, 1955) Elsik, 1977

Raphidodinium fucatum (Deflandre, 1936) Sarjeant and Downie, 1982

Spiniferites ramosus (Ehrenberg, 1837) Mantell 1854

Spongodinium delitiense (Ehrenberg, 1837) Lucas-Clark, 1987

Trichodinium castanea (Deflandre, 1935) Clarke and Verdier, 1967

Trithyrodinium evittii (Drugg, 1967) Nøhr-Hansen and Dam, 1999

Trithyrodinium suspectum (Manum and Cookson, 1964) Davey, 1969 
Data availability. The slide with the new species holotype is deposited at the Natural History Museum in the London palynology slide repository.

Author contributions. Both authors conceptualised and wrote the paper.

Competing interests. The authors declare that they have no conflict of interest.

Acknowledgements. The authors would like to thank A/S Norske Shell and RPS Energy Ltd. for permission to publish this research. The views expressed might not necessarily reflect the views of the company. RPS Energy Ltd. is also thanked for permission to use their laboratory facilities. The authors would also like to thank Peter Osterloff for his comments and support as well as Marc Gordon (Shell UK) for support with ArcGIS. Many thanks to the reviewers Stan Duxbury and Martin Pearce for their constructive comments and suggestions for improvement.

Review statement. This paper was edited by Francesca Sangiorgi and reviewed by Stan Duxbury and Martin Anthony Pearce.

\section{References}

Alberti, G.: Zur Kenntnis der Gattung Deflandrea Eisenack (Dinoflag.) in der Kreide und im Alttertiär Nord- und Mitteldeutschlands, Mitteilungen dem Geol. Staatsinst. Hamburg, 28, 93-105, 1959.

Bütschli, O.: Erster Band. Protozoa, in: Klassen und Ordnungen des Thier-Reichs, wissenschaftlich dargestellt in Wort und Bild, edited by: Bronns, H. G., C.F. Winter'sche Verlagsbuchhandlung, Leipzig and Heidelberg, 865-1088, 1885.

Cao, W., Zahirovic, S., Flament, N., Williams, S., Golonka, J., and Müller, R. D.: Improving global paleogeography since the late Paleozoic using paleobiology, Biogeosciences, 14, 5425-5439, https://doi.org/10.5194/bg-14-5425-2017, 2017.

Clarke, R. F. A. and Verdier, J.-P.: An investigation of microplankton assemblages from the Chalk of the Isle of Wight, England, Verhandelingen der Koninklijke Nederlandse Akademie van Wetenschappen, Afdeeling Natuurkunde, Eerste Reeks, 24, 1-96, 1967.

Cookson, I. C. and Eisenack, A.: Microplankton from Australian Lower Cretaceous sediments, Proceedings of the Royal Society of Victoria, 72, 1-11, 1960.

Costa, L. I. and Davey, R. J.: Dinoflagellate cysts of the Cretaceous System, in: A Stratigraphic Index of Dinoflagellate Cysts, edited by: Powell, A. J., Chapman and Hall, London, British Micropalaeontological Society Publication Series, 99-153, 1992.

Dam, G., Nøhr-Hansen, H., Christiansen, F. G., Bojesen-Koefoed, J. A., and Laier, T.: The oldest marine Cretaceous sediments in West Greenland (Umiivik-1 borehole) - record of the Cenomanian-Turonian Anoxic Event?, GEUS Bulletin, 180, 128-137, https://doi.org/10.34194/ggub.v180.5096, 1998.
Dam, G., Nøhr-Hansen, H., Pedersen, G., and Sønderholm, M.: Sedimentary and structural evidence of a new early Campanian rift phase in the Nuussuaq Basin, West Greenland, Cretaceous Res., 21, 127-154, 2000.

Davey, R. J.: Some dinoflagellate cysts from the Upper Cretaceous of northern Natal, South Africa, Palaeontologia Africana, 12, 123, 1969.

Davey, R. J.: The stratigraphic distribution of dinocysts in the Portlandian (latest Jurassic) to Barremian (Early Cretaceous) of northwest Europe, American Association of Stratigraphic Palynologists, Contributions Series, 5B, 48-81, 1979.

Deflandre, G.: Considérations biologiques sur les microorganisms d'origine planctonique conservés dans les silex de la craie, Bulletin biologique de la France et de la Belgique, 69, 213-244, 1935.

Deflandre, G.: Microfossiles des silex crétacés. Première partie. Généralités. Flagellés, Annales de paléontologie, 25, 151-191, 1936.

Deflandre, G. and Cookson, I. C.: Fossil microplankton from Australian Late Mesozoic and Tertiary sediments, Aust. J. Mar. Fresh. Res., 6, 242-313, 1955.

Drugg, W. S.: Palynology of the upper Moreno formation (late cretaceous-paleocene) escarpado canyon, California, Palaeontogr. Abt. B, 120, 1-71, 1967.

Duxbury, S.: A study of dinoflagellate cysts and acritarchs from the Lower Greensand (Aptian to Lower Albian) of the Isle of Wight, southern England, Palaeontogr. Abt. B, 186, 18-80, 1983.

Duxbury, S.: A Palynological Zonation Scheme for the Lower Cretaceous - United Kingdom Sector, Central North Sea, Neues Jahrb. Geol. P.-A., 219, 95-137, 2001.

Duxbury, S.: Berriasian to lower Hauterivian palynostratigraphy, U.K. onshore and Outer Moray Firth, Micropaleontology, 64, 171-252, 2018.

Ehrenberg, C. G.: Über das Massenverhältniss der jetzt lebenden Kiesel-Infusorien und über ein neues Infusorien-Conglomerat als Polirschiefer von Jastraba in Ungarn, Abhandlungen der Königlichen Akademie der Wissenschaften zu Berlin, aus dem Jahre 1836, Physikalische Klasse, 109-135, 1837.

Elsik, W. C.: Paralecaniella indentata (Defl. \& Cooks. 1955) Cookson and Eisenack 1970 and allied dinocysts, Palynology, 1, 95102, 1977.

Evitt, W. R.: The cretaceous microfossil Ophiobolus lapidaris O. Wetzel and its flagellum-like filaments, Stanford University publications, Stanford, CA, Geological Sciences, 12, 1-9, 1968.

Fensome, R. A., Taylor, F. J. R., Norris, G., Sarjeant, W. A. S., Wharton, D. I., and Williams, G. L.: A classification of living and fossil dinoflagellate, Micropaleontology special publication, 7, 351 pp., 1993.

Fensome, R. A., Williams, G. L., and MacRae, R. A.: Late Cretaceous and Cenozoic fossil dinoflagellates and other palynomorphs from the Scotian Margin, offshore Eastern Canada, J. Syst. Palaeontol., 7, 1-79, 2009.

Fensome, R. A., Williams, G. L., and MacRae, R. A.: The Lentin and Williams index of fossil dinoflagellates 2019 edition, AASP Contributions Series Number 50, 2019.

Gradstein, F. M., Anthonissen, E., Brunstad, H., Charnock, M., Hammer, Ø., Hellem, T., and Lervik, K. S.: Norwegian offshore stratigraphic lexicon (NORLEX), Newsl. Stratigr., 44, 73-86, 2010 . 
Jolley, D.: Palynofloral association sequence stratigraphy of the Palaeocene Thanet Beds and equivalent Sediments in eastern England, Rev. Palaeobot. Palyno., 74, 207-237, 1992.

Jolley, D.: Palynostratigraphy and depositional history of the Palaeocene Ormesby/Thanet depositional sequence set in southeastern England and its correlation with Continental West Europe and the Lista Formation, North Sea, Rev. Palaeobot. Palyno., 99, 265-315, 1998 .

Kairanov, B., Escalona, A., Mordasova, A., Śliwińska, K., and Suslova, A.: Lower Cretaceous tectonostratigraphic evolution of the northcentral Barents Sea, J. Geodynam., 119, 183-198, 2018.

Lejeune-Carpentier, M.: L'étude microscopique des silex. Areoligera: nouveau genre d'Hystrichosphaeridée, Sixième note, Annales de la Société Géologique de Belgique, 62, B163-B174, 1938.

Lentin, J. K. and Williams, G. L.: A monograph of fossil peridinioid dinoflagellate cysts, Bedford Institute of Oceanography, Report Series, no. BI-R-75-16, 237 pp., 1976.

Lentin, J. K. and Williams, G. L.: Fossil dinoflagellates: index to genera and species, 1985 edn., Canadian Technical Report of Hydrography and Ocean Sciences, 60, 451 pp., 1985.

Lentin, J. K. and Williams, G. L.: Status of the fossil dinoflagellate genera Ceratiopsis Vozzhennikova 1963 and Cerodinium Vozzhennikova 1963 emend, Palynology, 11, 113-116, 1987.

Lentin, J. K. and Vozzhennikova, T. F.: Fossil dinoflagellates from the Jurassic, Cretaceous and Paleogene deposits of the USSR a re-study, American Association of Stratigraphic Palynologists, Contributions Series, 23, 221 pp., 1990.

Loeblich III., A. R.: Notes on the divisions Chlorophyta, Chrysophyta, Pyrrhophyta and Xanthophyta and the family Paramastigaceae, Taxon, 16, 230-237, 1967.

Lucas-Clark, J.: Wigginsiella n. gen., Spongodinium, and Apteodinium as members of the Aptiana-Ventriosum complex (fossil Dinophyceae), Palynology, 11, 155-184, 1987.

Lyck, J. M. and Stemmerik, L.: Palynology and depositional history of the Paleocene? Thyra $\varnothing$ formation, Wandel Sea basin, eastern North Greenland, Geol. Surv. Den. Greenl., 187, 21-49, 2000.

Mantell, G. A.: The Medals of Creation; or, First Lessons in Geology and the Study of Organic Remains, 2nd edn., Henry G. Bohn, London, UK, 930 p., 1854.

Manum, S. B. and Cookson, I. C.: Cretaceous microplankton in a sample from Graham Island, arctic Canada, collected during the second "Fram" expedition (1898-1902). With notes on microplankton from the Hassel Formation, Ellef Ringnes Island, Norske Videnskaps-Akademi i Oslo, I. MatematiskNaturvidenskapelig Klasse, Skrifter, Ny Serie, 17, 1-36, 1964.

Monteil, E.: Quelques nouvelles espèces-index de kystes de dinoflagellés (Tithonique-Valanginien) du sud-est de la France et de l'ouest de la Suisse, Paléobiologie, 11, 273-297, 1992.

Nøhr-Hansen, H.: Dinoflagellate cyst stratigraphy of the Barremian to Albian, Lower Cretaceous, Northeast Greenland, Geologic survey of Denmark and Greenland Bulletin, 166, 171 pp., 1993.

Nøhr-Hansen, H.: Dinoflagellate cyst biostratigraphy of the Upper Cretaceous black mudstones on Svartenhuk Halvø, West Greenland, Open File Series Grønlands Geologiske Undersøgelse, 94/9, 25 pp., 1994a.

Nøhr-Hansen H.: Dinoflagellate cyst biostratigraphy of the Upper Cretaceous black mudstones in central Nuussuaq, West Green- land, Open File Series Grønlands Geologiske Undersøgelse, 94/12, 26 pp., 1994b.

Nøhr-Hansen H.: Dinoflagellate cyst biostratigraphy of the Upper Cretaceous black mudstones between Niaqornatand Ikorfat on the north coast of Nuussuaq, West Greenland, Open File Series Grønlands Geologiske Undersøgelse, 94/14, 24 pp., 1994c.

Nøhr-Hansen, H.: Upper Cretaceous dinoflagellate cyst stratigraphy, onshore West Greenland, Bulletin GrønlandsGeologiske Undersøgelse, 170, 104 pp., 1996.

Nøhr-Hansen, H.: Palynostratigraphy of the Cretaceous-lower Palaeogene sedimentary succession in the Kangerlussuaq Basin, southern East Greenland, Rev. Palaeobot. Palyno., 178, 59-90, 2012.

Nøhr-Hansen, H. and Dam, G.: Trithyrodinium evittii Drugg 1967 and T. fragile Davey 1969 an artificial split of one dinoflagellate cyst species - stratigraphic and palaeoenvironmental importance, Grana, 38, 125-133, 1999.

Nøhr-Hansen, H. and McIntyre, D. J.: Upper Barremian to Upper Albian (Lower Cretaceous) dinoflagellate cyst assemblages, Canadian Arctic Archipelago, Palynology, 22, 143-166, 1998.

Ogg, G.: Dinoflagellate cysts of the Early Cretaceous North Atlantic Ocean, Mar. Micropaleontol., 23, 241-263, 1994.

Pascher, A.: Über Flagellaten und Algen, Deutsche Botanische Gesellschaft, Berichte, 32, 136-160, 1914.

Pearce, M. A.: New organic-walled dinoflagellate cysts from the Cenomanian to Maastrichtian of the Trunch borehole, UK, J. Micropalaeontol., 29, 51-72, 2010.

Radmacher, W., Tyszka, J., and Mangerud, G.: Distribution and biostratigraphical significance of Heterosphaeridium bellii sp. nov. and other Upper Cretaceous dinoflagellate cysts from the southwestern Barents Sea, Rev. Palaeobot. Palyno., 201, 29-40, 2014a.

Radmacher, W., Tyszka, J., Mangerud, G., and Pearce, M. A.: Dinoflagellate cyst biostratigraphy of the Late Albian to Early Maastrichtian in the southwestern Barents Sea, Mar. Petrol. Geol., 57, 109-121, 2014b.

Radmacher, W., Mangerud, G., and Tyszka, J.: Dinoflagellate cyst biostratigraphy of Upper Cretaceous strata from two wells in the Norwegian Sea, Rev. Palaeobot. Palyno., 216, 18-32, 2015.

Sarjeant, W. A. S.: The genus Palaeoperidinium Deflandre (Dinophyceae). Grana palynologica, Stockholm, 7, 243-258, 1967.

Sarjeant, W. A. S. and Downie, C.: The Upper Cretaceous dinoflagellate cyst Raphidodinium Deflandre: a restudy, Grana, 21, 115120, 1982.

Scotese, C. R., Boucot, A. J., and Xu, Chen: Atlas of Phanerozoic Climatic Zones (Mollweide Projection), Volumes 1-6, PALEOMAP Project PaleoAtlas for ArcGIS, PALEOMAP Project, Evanston, IL, 2014.

Setoyama, E., Radmacher, W., Kaminski, M. A., and Tyszka, J.: Foraminiferal and palynological biostratigraphy and biofacies from a Santonian-Campanian submarine fan system in the Vøring Basin (offshore Norway), Mar. Petrol. Geol., 43, 396-408, 2013.

Stover, L. E. and Evitt, W. R.: Analyses of pre-Pleistocene organicwalled dinoflagellates, Stanford University Publications, Stanford, CA, Geological Sciences, 15, 300 pp., 1978.

Taylor, F. J. R.: On dinoflagellate evolution, BioSystems, 13, 65$108,1980$. 
Torricelli, S.: Lower Cretaceous dinoflagellate cyst and acritarch stratigraphy of the Cismon APTICORE (Southern Alps, Italy), Rev. Palaeobot. Palyno., 108, 213-266, 2000.

Vieira, M. and Jolley, D.: Stratigraphic and spatial distribution of palynomorphs in deep-water turbidites: a meta-data study from the UK Central North Sea Paleogene, Mar. Petrol. Geol., 122, 104638, https://doi.org/10.1016/j.marpetgeo.2020.104638, 2020.

Vieira, M., Mahdi, S., Casas-Gallego, M., and Fenton, J.: Three new Paleocene dinoflagellate cysts from the North Sea and the Norwegian Sea, Rev. Palaeobot. Palyno., 258, 256-264, https://doi.org/10.1016/j.revpalbo.2018.09.002, 2018a.

Vieira, M., Mahdi, S., and Osterloff, P.: New Early Paleocene (Danian) dinoflagellate cyst species from the Ormen Lange Field, Møre Basin, Norwegian Continental Shelf, Palynology, 42, 180198, https://doi.org/10.1080/01916122.2017.1314390, 2018b.

Vieira, M., Mahdi, S., and Holmes, N.: High resolution biostratigraphic zonation for the UK Central North Sea Paleocene, Mar. Petrol. Geol., 117, 104400, https://doi.org/10.1016/j.marpetgeo.2020.104400, 2020.

Vozzhennikova, T. F.: Iskopaemye peridinei Yurskikh, Melovykh i Paleogenovykh otlozheniy SSSR, Izdatelstvo Nauka, Moscow, U.S.S.R. 347 pp., 1967.
Warren, J. S.: Dinoflagellates and acritarchs from the Upper Jurassic and Lower Cretaceous rocks on the west side of the Sacramento Valley, California, Stanford University, PhD dissertation, unpublished, 409 pp., 1967.

Wetzel, O.: Die in organischer Substanz erhaltenen Mikrofossilien des baltischen Kreide-Feuersteins mit einem sedimentpetrographischen und stratigraphischen Anhang, Palaeontogr. Abt. A, 77, 141-186, 1933.

Williams, G. L., Fensome, R. A., Miller, M. A., and Sarjeant, W. A. S.: A glossary of the terminology applied to dinoflagellates, acritarchs and prasinophytes, with emphasis on fossils, 3rd edn., American Association of Stratigraphic Palynologists: Contributions Series, 37, 370 pp., 2000.

Williams, G. L., Brinkhuis, H., Pearce, M. A., Fensome, R. A., and Weegink, J. W.: Southern Ocean and global dinoflagellate cyst events compared: index events for the Late Cretaceous-Neogene, in: Proceedings of the Ocean Drilling Program, Scientific Results, 189, edited by: Exon, N. F., Kennett, J. P., and Malone, M. J., Ocean Drilling Program, Texas, 1-98, 2004.

Wilson, G. J.: Microplankton from the Garden Cove Formation, Campbell Island, New Zeal. J. Bot., 5, 223-240, 1967. 